\title{
KEBIJAKAN DAN STRATEGI PENING- KATAN KOMPETENSI GURU SERTA RELEVANSINYA TERHADAP MUTU LULUSAN YANG ISLAMI
}

\begin{abstract}
Abstrak:
Oleh:

Maskuri

Khairul Anwar

Email:

masykuri.ismail@gmail.com

anwrabizidan@gmail.com

Universitas Ibrahimy

Teacher as the first position in reaching educational vision and mission, because of that teacher has an important role to upgrade their quality. Besides that, teacher has to enhance their competence. So has many implementerpolicies of national education system released to support teacher's competence enhancement. Donations, education facilities, training allocated for teachers by country be an opportunity to make innovative and creative work. Teacher be approved by the nation not only limited at legal formal, but also by providing financial right as appreciation for great earnings. By the several teacher's competencies, including holistic, integrative, religious, so that institutional education will produce qualified graduates, competitive, independence, and responsibility to solve educational problems, like moral decadention. To make easier for teacher competency improvement strategies, so school as one of the institutional education bas to do better planning through the process of analysis. The totality of school or madrasah management can produce good and correct quality education.
\end{abstract}

Keyword: Educational Policy, Teacher Competence, Improvement strategy

\section{PENDAHULUAN}

Sampai saat ini, usaha untuk menjadikan lembaga pendidikan agar bermutu terus dilakukan, baik pemerintah maupun masyarakat sebagai penyelenggara pendidikan. Masih banyak yang mempertanyakan kualitas lulusan pendidikan. Seperti yang disampaikan oleh Berry Priyono, sebagaimana yang telah ditulis Kunandar bahwa lulusan atau peserta didik yang telah mengikuti proses pembelajaran di lingkungan sekolah lebih banyak menerima materi pelajaran secara teoritik, minim praktik. Sehingga para lulusan pendidikan tidak memiliki sikap mandiri. ${ }^{1}$ Membentuk peserta didik agar memiliki kemandirian merupakan tujuan pendidikan, sebagaimana disebutkan dalam pasal 3 Undang-Undang Nomor 20 Tahun 2003 tentang Sistem Pendidikan Nasonal. Jiwa mandiri sebagai salah satu tujuan pendidikan harus dibentuk melalui proses pendidikan yang bermutu. Adapun yang

\footnotetext{
${ }^{1}$ Kunandar, Guru Profesional, Implementasi Kurikulum Tingkat Satuan Pendidikan (KTSP) dan Sukses dalam Sertifikasi Guru (Jakarta: Rajawali Press, 2011), 1.
}

disampaikan Berry dalam analisisnya merupakan proses refleksi penyelenggaraan pendidikan, yang selama ini memang terkesan mengedepan aspek kognitif. Ini bisa dijadikan bahan renungan dan evaluasi bagi seluruh penyelenggara dan pengelola pendidikan.

Sebagai upaya peningkatan mutu pendidikan, dengan salah satu indikator lulusan, maka pemerintah terus melakukan berbagai inovasi dan penyempurnaan kebijakan. Nampaknya perubahan kurikulum menjadi tren model kebijakan yang selalu terjadi dari waktu ke waktu dalam setiap periode kepemimpinan pendidikan secara nasional. Secara ilmiah, perubahan kurikulum itu memang dibenarkan, karena perubahan adalah kata, bahkan mitos yang selalu menjadi isu strategis bagi pengambil kebijakan. Faktanya, perubahan kurikulum kadang "berbuah konflik" yang menguras pikiran dan tenaga, terutama para pelaksana pendidikan pada satuan pendidikan. Dalam kajian sosiologi, ada hubungan yang tidak bisa dipisahkan antara sistem pendidikan dengan aspek lain yang berkembang dalam kehidupan masyarakat. 
Sistem pendidikan yang ada pasti akan bersinggungan dengan sistem sosial, kekuasaan, kebudayaan, kultur, dan banyak lagi lainnya. Jadi wajar bila kemudian negara, dalam hal ini Kementerian Pendidikan dan kebudayaan, secara terus menerus menggunakan sistem kekuasaannya untuk melakukan perubahan dalam sistem pendidikan. Pertanyaannya, apakah perubahan itu membawa dampak terhadap mutu penyelenggaraan pendidikan atau tidak?

Sejarah telah membuktikan bahwa pendidikan memang selalu mengalami perubahan. Sejalan dengan apa yang termaktub dalam teori filsafat pendidikan yang melandasi terhadap perubahan paradigmatik dalam pendidikan. Namun, bangunan paradigmatik dalam pendidikan kadang tidak berbanding lurus antara konsep dan praktis. Malah yang muncul merupakan konflik pada tataran teknis penyelenggaraan pendidikan. Seperti dikatakan Syafiq A. Mughni, bahwa pada tataran konseptual, perubahan pendidikan masih terfokus pada tataran normatif-formalistis, dan ini sesungguhnya bukan esensi dari proses pendidikan itu sendiri. ${ }^{3}$ Konsep perubahan harus benar-benar memiliki dampak kebermanfaatan, bukan sekedar konsep dan teori, harus implementatif. Apalagi perubahan menyangkut pengelolaan pendidikan yang harus membaca peluang dan tantangan yang ada. Guru, sebagai ujung tombak pelaksanaan pendidikan harus diperhatikan semua aspek kompetensinya.

Dalam konteks pelaksanaan kurikulum, guru atau pendidik menjadi faktor yang paling dominan. Seringkali guru dibuat pusing oleh kebijakan pemerintah melakukan perubahan kurikulum secara temporer. Argumentasi yang sering dikemukakan oleh pemerintah biasanya menggunakan pendekatan inovasi. Bahwa salah satu penyesuaian kurikulum pendidikan adalah karena tuntutan inovasi dan adaptasi terhadap perkembangan ilmu pengetahuan dan teknologi. Alasan lain yang justru mengemukan bukan soal inovasi, tapi pada gaya kepemimpinan dalam pemerintahan. Nampaknya tidak dianggap keren dan sukses kalau tidak melakukan perubahan

\footnotetext{
${ }^{2}$ Mahmud, Sosiologi Pendidikan (Bandung: Pustaka Setia, 2012), 17.

3 Syafiq A. Mughni, "Paradigma Pendidikan Universal di Era Modern dan Post-Modern dalam Ali Maksum dan Luluk Yunan Ruhendi, Paradigma Pendidikan Universal di Era Modern dan Post-Modern (Yogyakarta: IRCiSoD, 2004), 5.
}

kebijakan. Memang benar, bahwa sebagian alasan perubahan atau penggantian peraturan perundangundangan adalah adanya tuntutan terhadap penyesuaian dinamika perkembangan. Padahal Undang-Undang yang mengatur sistem pendidikan nasional, proses penggantiannya tidak begitu cepat dan tidak sering dilakukan. Faktor yang membuat sering berubah dan dilakukan waktu dengan serba mendadak biasanya keterkaitan dengan peraturan tentang petunjuk pelaksanaan dan teknis. Satu produk aturan belum selesai dipahami, aturan lain sudah muncul secara bersamaan. Belum lagi jika menyangkut penyelenggaraan pendidikan yang dilakukan oleh dua kementerian, Pendidikan Nasional dan Agama, yang sama-sama diberi kewenangan urusan pemerintahan di bidang pendidikan (umum dan agama).

Fokus kajian dalam tulisan ini akan membahas tentang bagaimana guru sebagai ujung tombak dalam proses penyelenggaraan dan pengelolaan pendidikan mempersiapkan diri secara matang dan profesional. Apalah arti sistem dan regulasi pendidikan, jika guru atau pendidik tidak bisa melaksanakannya dengan baik dan benar. Karena itu, guru harus terus berupaya melakukan proses peningkatan kompetensi atau kapasitas agar proses pembelajaran benar-benar dapat diterima oleh peserta didik. Sekolah atau madrasah sebagai satuan pendidikan akan dikatakan maju dan berkualitas manakala menghasilkan lulusan yang berkualitas. Adapun ini membutuhkan sosok guru yang profesional dan memiliki kompetensi.

\section{PEMBAHASAN}

\section{Kebijakan Kompetensi Guru}

Sebelum beranjak pada fokus kajian kebijakan kompetensi guru, maka pengertian tentang guru sangatlah penting dibahas, bagaimana fungsi dan tujuan pendidikan serta standar nasional pendidikan? Penjelasan ini menjadi penting karena satu sama lain memiliki keterkaitan yang sangat urgen dalam proses penyelenggaraan dan pengolaan pendidikan. Secara normatif, guru sebagaimana disebutkan dalam Undang-Undang Republik Indonesia Nomor 14 Tahun 2005 tentang Guru dan Dosen pasal 1 angka 1, bahwa guru adalah pendidik profesional dengan tugas utama mendidik, mengajar, membimbing, mengarahkan, melatih, menilai, dan mengevaluasi 
peserta didik pada pendidikan anak usia dini jalur pendidikan formal, pendidikan dasar, dan pendidikan menengah. Kemudian, sebelum regulasi yang mengatur guru dan dosen tersebut, dalam UndangUndang Nomor 20 Tahun 2003 tentang Sistem Pendidikan Nasional pasal 1 angka 6, disebutkan bahwa pendidik adalah tenaga kependidikan yang berkualifikasi sebagai guru, dosen, konselor, pamong praja, widyaiswara, tutor, instruktur, fasilitator, dan sebutan lainnya yang sesuai dengan kekhususan, serta berpartisipasi dalam menyelenggarakan pendidikan.

Ada dua hal yang juga perlu dijelaskan, yaitu pendidik profesional dan kualifikasi akademik seorang guru. Secara etimologi, profesi berasal dari bahasa Inggris, profession atau bahasa latin, profecus, artinya ada pengakuan terhadap suatu keahlian dalam bidang pekerjaan tertentu. Sedangkan secara terminologi, profesi itu suatu pekerjaan yang mensyaratkan adanya proses akademik dan teoritik sebagai instrumen dalam melakukan pekerjaan. ${ }^{4}$ Profesi itu suatu pekerjaan atau jabatan yang memerlukan keahlian tertentu, dan untuk memperoleh keahlian tersebut harus dilakukan melalui proses pendidikan dan pelatihan. ${ }^{5}$ Tidak semua orang yang melakukan pekerjaan disebut sebagai profesi, sekalipun profesi itu sendiri merupakan pekerjaan. Kebutuhan terhadap pemenuhan profesi harus dilakukan melalui proses akademik dan atau pelatihan keahlian tertentu. Menurut pasal 1 angka 4 UU Nomor 14 Tahun 2005 tentang Guru dan Dosen, profesional adalah pekerjaan atau kegiatan yang dilakukan oleh seseorang dan menjadi sumber penghasilan kehidupan yang memerlukan keahlian, kemahiran, atau kecakapan yang memenuhi standar mutu atau norma tertentu serta memerlukan pendidikan profesi. Sedangkan pengertian kualifikasi akademik disebutkan dalam pasal 1 angka 9, yaitu ijazah jenjang pendidikan akademik yang harus dimiliki oleh guru atau dosen sesuai dengan jenis, jenjang, dan satuan pendidikan formal di tempat penugasan. Kompetensi adalah seperangkat pengetahuan, keterampilan, dan perilaku yang harus dimiliki, dihayati, dan dikuasai

\footnotetext{
${ }^{4}$ Rusman, Model-Model Pembelajaran; Mengembangken Profesionalisme Guru (Jakarta: Raja Grafindo Persada, 2011), 17.

${ }^{5}$ Kunandar, Guru Profesional, Implementasi Kurikulum Tingkat Satuan Pendidikan (KTSP) dan Sukeses dalam Sertifikasi Guru (Jakarta: Rajawali Press, 2011), 45.
}

oleh guru atau dosen dalam melaksanakan tugas keprofesionalannya. ${ }^{6}$ Menurut Peraturan Pemerintah Nomor 19 Tahun 2017 tentang Perubahan atas Peraturan Pemerintah Nomor 74 Tahun 2008 tentang Guru, kualifikasi akademik adalah ijazah jenjang pendidikan akademik yang harus dimiliki oleh guru sesuai dengan jenis, jenjang, dan satuan pendidikan formal di tempat penugasan.

Nampaknya tidak mudah untuk mengkategorikan seorang guru disebut sebagai pendidik profesional yang sekaligus memiliki kompetensi. Ketika seseorang dikategorikan sebagai kompeten maka ia harus memiliki berbagai perangkat pengetahuan, keterampilan, dan perilaku. Bukan sekedar penguasaan terhadap teori dan segala regulasi, tetapi harus ada komitmen terhadap apa yang dikuasai dengan penghayatan perilaku kesehariannya. Ada tanggung jawab moral yang menjadi beban guru dalam proses penyenggaraan dan pengelolaan pendidikan. Guru juga harus memenuhi standar profesional agar dalam proses pembelajaran dan pola pergaulan di lingkungan sekolah atau madrasah menampakkan sebagai orang yang memiliki jiwa pendidik. Ketentuan mengenai standar guru profesional itu diatur dalam beberapa regulasi. Peraturan Pemerintah Nomor 32 Tahun 2013 tentang Perubahan Peraturan Pemerintah Nomor 19 Tahun 2005 tentang Standar Nasional Pendidikan menjadi landasan pokok dalam pengaturan mengenai standar guru sebagai pendidik. Adapun delapam standar yang diatur dalam PP tersebut, salah satunya adalah standar pendidik dan tenaga kependidikan. ${ }^{7}$ Ada keharusan bagi guru untuk memiliki kualifikasi akademik dan kompetensi secara holistik dan terintegrasi. Kompetensi yang harus dimiliki adalah kompetensi pedagogik, kepribadian, profesional, dan sosial. Secara khusus, ketentuan tentang standar pendidik, sebagaimana dimaksud dalam PP 19 Tahun 2005 tentang SNP diatur dalam pasal 28 sampai 34 .

Mengapa guru harus profesional dan memiliki kompetensi? Karena unsur penting dalam proses pembelajaran, adalah kehadiran guru bagi peserta didik. Kebutuhan guru profesional

\footnotetext{
${ }^{6}$ Undang-Undang Republik Indonesia Nomor 14 Tahun 2005 tentang Guru dan Dosen.

7 Standar Pendidik dan Tenaga Kependidikan, pasal 1 angka 7 PP Nomor 19 Tahun 2005 tentang Standar Nasional Pendidikan.
} 
akan mengantarkan peserta didik dalam proses pembelajaran berkembang dengan baik. Pemerintah menyusun berbagai regulasi yang mengatur tentang standarisasi guru dimaksudkan agar tujuan nasional pendidikan yang telah disepakati sebagai keputusan politik dapat tercapai. Penetapan standar nasional pendidikan oleh pemerintah berfungsi sebagai dasar dalam perencanaan, pelaksanaan, dan pengawasan pendidikan dalam rangka mewujudkan pendidikan nasional yang bermutu. Sedangkan tujuannya menjamin mutu Pendidikan nasional dalam rangka mencerdaskan kehidupan bangsa dan membentuk watak serta peradaban bangsa yang bermartabat. ${ }^{8}$ Ketercapaian pendidikan yang bermutu tentu membutuhkan kompetensi guru sebagai pendidik profesional.

Para penyelenggara dan pengelola pendidikan perlu tahu visi dan misi pendidikan nasional, sebagaimana disebutkan dalam penjelasan umum PP Nomor 19 Tahun 2005 tentang Standar Nasional Pendidikan, bahwa visi pendidikan nasional adalah mewujudkan sistem pendidikan sebagai pranata sosial yang kuat dan berwibawa untuk memberdayakan semua warga negara Indonesia agar berkembang menjadi manusia yang berkualitas sehingga mampu dan proaktif menjawab tantangan zaman yang selalu berubah. Sedangkan misi pendidikan nasional adalah: (1) mengupayakan perluasan dan pemerataan kesempatan memperoleh pendidikan yang bermutu bagi seluruh rakyat Indonesia; (2) meningkatkan mutu pendidikan yang memiliki daya saing di tingkat nasional, regional, dan internasional; (3) meningkatkan relevansi pendidikan dengan kebutuhan masyarakat dan tantangan global; (4) membantu dan memfasilitasi pengembangan potensi anak bangsa secara utuh sejak usia dini sampai akhir hayat dalam rangka mewujudkan masyarakat belajar; (5) meningkatkan kesiapan masukan dan kualitas proses pendidikan untuk mengoptimalkan pembentukan kepribadian yang bermoral; (6) meningkatkan keprofesionalan dan akuntabilitas lembaga pendidikan sebagai pusat pembudayaan ilmu pengetahuan, keterampilan, pengalaman, sikap, dan nilai berdasarkan standar yang bersifat nasional dan global; dan (7) mendorong peran serta masyarakat dalam penyelenggaraan pendidikan berdasarkan prinsip otonomi dalam konteks Negara Kesatuan Republik Indonesia.

\footnotetext{
${ }^{8}$ PP Nomor 19 Tahun 2005 pasal 3 dan pasal 4
}

Kerja keras dan upaya inovatif dari pemerintah sebagai pengambil kebijakan sekaligus penanggung jawab penyelenggaraan dan pengelolaan pendidikan tidak hanya sekedar memenuhi target normatif dalam membentuk peraturan perundang-undangan. Lebih dari itu, pemerintah harus bisa adaptif dan proaktif dalam membaca situasi kebatinan guru sebagai pendidik yang akan mengantarkan manusia Indonesia yang berkualitas dan mampu merespon tantangan perubahan. Perlu diingat, bahwa ada faktor pendukung dala, hal ini keberhasilan dan juga penghambat dalam konteks ini merupakan kegagalan perubahan. Menurut Robbins, sebagaimana ditulis Wibowo, ada enam faktor kekuatan yang menyebabkan perubahan itu terjadi, yaitu (1) teknologi yang begitu cepat; (2) persaingan yang semakin ketat; (3) perekonomian yang mengejutkan; (4) perubahan sistem politik atau kekuasaan; (5) kecenderungan masyarakat terhadap sesuatu yang bersifat baru; (6) sifat tenaga kerja yang membutuhkan kompetensi dan keahlian khusus. ${ }^{9}$ Pemerintah dengan berdalih, adanya pergantian sistem politik dan kekuasaan serta tuntutan perkembangan teknologi yang begitu cepat, maka suatu keniscayaan jika perubahan itu harus dilakukan. Pendidik, guru dan dosen harus bisa merespon seluruh dinamika perubahan, sehingga tidak perlu kaget.

Perubahan yang dilakukan oleh pemerintah dalam sistem penyelenggaraan dan pengelolaan pendidikan bisa saja mengalami kegagalan. Untuk itu harus ada kesiapan mental bagi para aktor pelaksana kebijakan pendidikan. Hussey dalam Nur Efendi mengidentifikasi adanya kegagalan perubahan, antara lain (1) butuh waktu lama untuk penyesuaian dalam pelaksanaan; (2) koordinasi yang kurang cepat dan tepat; (3) pelaksana kebijakan yang masih kurang kapabel; (4) waktu yang digunakan untuk sosialisasi dan pelatihan tidak cukup; (5) faktor eksternal yang sulit dikendalikan dan tidak diantisipasi; (6) sistem informasi yang tersedia tidak cukup memadai sehingga terjadi miss-information, dan sebagainya. ${ }^{10}$ Tentu, guru sebagai pendidik profesional harus bisa memenuhi tuntutan kompetensi, baik melalui proses akademik maupun forum-forum lain, seperti seminar, lokakarya, pelatihan, dan lain sebagainya.

\footnotetext{
9 Wibowo, Manajemen Perubaban (Jakarta: Rajagrafindo, 2006), 83.

${ }^{10}$ Nur Efendi, Manajemen Perubahan di Pondok Pesantren (Yogyakarta: Teras, 2014), 41.
} 


\section{Kompetensi Guru}

Setelah memahami alur kebijakan pemerintah yang mengatur kompetensi guru, bahasan selanjutnya adalah bagaimana kita memahami kompetensi guru, secara teoritik maupun praktik atau pelaksanaannya dalam proses penyelenggaraan pendidikan. Secara implementatif, sebenarnya kompetensi guru dapat dilihat ketika terjadi interaksi antara guru dengan siswa dalam proses pembelajaran. Secara etimologi, kompetensi merupakan kata serapan dari bahasa Inggris, yaitu competence yang memiliki terjemahan kemampuan atau kecakapan. Mulyasa, sebagaimana yang ditulis oleh Jejen Musfah, kompetensi guru merupakan perpaduan berbagai kemampuan; personal, teknologi, keilmuan, sosial, dan spiritual. Secara holistik kompetensi seseorang mencakup banyak ragam penguasaan materi, memahami aspek psikologi peserta didik, proses pembelajaran yang benar-benar mendidik, pengembangan karakteri pribadi, dan tuntutan profesionalitas. ${ }^{11}$

Keberhasilan seseorang dalam menjalankan kompetensinya bukan hanya terletak pada pelaksanaan tugas secara individu, ada penilaian lain menyangkut bagaimana seseorang melakukan kerja sama dengan orang lain. Tidak menggunakan pola one man show dalam bekerja ketika berada pada tim kerja. Kemampuan individu untuk mendukung peningkatan kompetensi dapat dilakukan dengan cara mengikuti pelatihan dan ikut serta dalam kegiatan di berbagai forum. Membangun kerja sama dalam sebuah tim memerlukan kepekaan sosial, wawasan lingkungan kerja, dan kesadaran untuk bisa mengevaluasi diri secara bersama. Semakin banyak pengalaman dalam pekerjaan, seseorang akan semakin matang dalam meningkatkan kompetensinya. Guru akan semakin terlihat memiliki kompetensi ketika mereka berada dalam komunitas lain, bukan sekedar dalam proses pembelajaran di ruang kelas. Ada proses lain untuk mengetahui tingkat kompetensi seseorang.

Dalam percakapan sehari-hari kita sering mendengar, bahwa kata guru itu kepanjangan dari digugu dan ditiru. Pengertian guru semacam ini muncul dalam persepsi masyarakat, karena guru adalah sosok teladan bagi kehidupan bermasyarakat, bukan hanya di lingkungan sekolah. Kompetensi yang

\footnotetext{
${ }^{11}$ Jejen Musfah, Peningkatan Kompetensi Guru Melalui Pelatiban dan Sumber Belajar Teori dan Praktik (Jakarta: Kencana Prenada Media Group, 2012), 27.
}

terkait dengan interaksi guru di tengah kehidupan masyarakat disebut dengan kompetensi sosial. Interaksi guru di luar sekolah memerlukan kepekaan sosial dan kepedulian dalam merespon dinamika kehidupan masyarakat. Membentuk kepekaan sosial membutuhkan latihan dan pola hidup pembiasaan, gambaran pergaulan di lingkungan sekolah dan proses pembelajaran di ruang kelas bersama peserta didik akan tercermin juga dalam pola pergaulan di tengah masyarakat.

Sebagai sosok guru, tentu akan menjadi idola bagi anak didiknya, oleh karenanya seorang guru harus bisa menempatkan diri. Bagaimana membedakan pergaulan ketika di sekolah dan lingkungan masyarakat ketika harus bersama-sama dengan anak didiknya. Apalagi Ketika anak pada usia masa menempuh pendidikan dasar atau menengah, mereka belum menemukan jati dirinya, masih pada tahap pencarian identitas. Mereka akan mencari contoh atau idola sebagai kebanggaan dalam pola pergaulan. Dalam pandangan siswa, guru sangat berperan sebagai model bagi siswanya. Sebab itulah guru harus bisa mengembangkan proses pembelajaran yang menarik agar siswa dapat mengekspresikan ide-ide dan kreatifitasnya. ${ }^{12}$ Guru tentu pernah mengikuti proses pendidikan pada saat kuliah, selain materi tentang keguruan, ada juga materi kuliah yang berkaitan dengan ilmu yang mempelajari hubungan manusia di tengah masyarakat, yaitu sosiologi.

Untuk mengetahui apa saja kompetensi guru dan bagaimana seharusnya guru memahaminya, perlu dijelaskan satu persatu. Sebagaimana disebutkan dalam PP Nomor 19 Tahun 2005 tentang Standar Nasional Pendidikan pasal 28 ayat (3) dan penjelasannya, kompetensi sebagai agen pembelajaran pada jenjang pendidikan dasar dan menengah serta pendidikan anak usia dini meliputi:

1. Kompetensi pedagogik, yaitu kemampuan mengelola pembelajaran peserta didik yang meliputi pemahaman terhadap peserta didik, perancangan dan pelaksanaan pembelajaran, evaluasi hasil belajar, dan pengembangan peserta didik untuk mengaktualisasikan berbagai potensi yang dimilikinya.

\footnotetext{
${ }^{12}$ Jamil Suhartiningrum, Guru Profesional; Pedoman Kinerja, Kualifikasi, dan Kompetensi Guru (Yogyakarta: Ar-Ruzz Media, 2014), 65.
} 
2. Kompetensi kepribadian, yaitu kemampuan kepribadian yang mantap, stabil, dewasa, arif, dan berwibawa, menjadi teladan bagi peserta didik, dan berakhlak mulia.

3. Kompetensi profesional, yaitu kemampuan penguasaan materi pembelajaran secara luas dan mendalam yang memungkinkannya membimbing peserta didik memenuhi standar kompetensi yang ditetapkan dalam Standar Nasional Pendidikan.

4. Kompetensi sosial, yaitu kemampuan pendidik sebagai bagian dari masyarakat untuk berkomunikasi dan bergaul secara efektif dengan peserta didik, sesama pendidik, tenaga kependidikan, orang tua atau wali peserta didik, dan masyarakat sekitar.

Masing-masing kompetensi tersebut memiliki standar sebagaimana diatur dalam Peraturan Menteri Pendidikan Nasional Nomor 16 Tahun 2007 tentang Standar Kualifikasi Akademik dan Kompetensi Guru, yaitu:

1. Kompetensi pedagogik terdiri dari 10 standar, yaitu (a) menguasai karakteristik peserta didik dari aspek fisik, moral, sosial, kultural, emosional, dan intelektual; (b) menguasai teori belajar dan prinsip-prinsip pembelajaran yang mendidik; (c) mengembangkan kurikulum yang terkait dengan mata pelajaran atau bidang pengembangan yang diampu; (d) menyelenggarakan pembelajaran yang mendidik; (e) memanfaatkan teknologi informasi dan komunikasi dalam proses pembelajaran; (f) memfasilitasi pengembangan potensi peserta didik; (g) berkomunikasi secara efektif, empatik, dan santun dengan peserta didik; (h) melaksanakan kegiatan penilaian dan evaluasi proses dan hasil belajar; (i) hasil penilaian dan evaluasi dimanfaatkan untuk kepentingan pembelajaran; (j) melakukan tindakan reflektif untuk peningkatan kualitas pembelajaran.

2. Kompetensi kepribadian, standarnya terdiri dari, (a) bertindak sesuai dengan norma agama, hukum, sosial, dan kebudayaan nasional Indonesia; (b) bekepribadian jujur, berakhlak mulia, dan teladan bagi peserta didik dan masyarakat; (c) memiliki pribadi yang mantap, stabil, dewasa, arif, dan berwibawa; (d) menunjukkan etos kerja, tanggung jawab yang tinggi, rasa bangga menjadi guru, dan rasa percaya diri, (e) menjunjung tinggi kode etik profesi guru.

3. Kompetensi profesional, yakni terdiri dari, (a) menguasai materi, struktur, konsep, dan pola pikir keilmuan; (b) menguasai materi mata pelajaran atau bidang pengembangan yang diampu; (c) mengembangkan materi pembelajaran yang diampu secara kreatif; (d) mengembangkan keprofesionalan secara berkelanjutan dengan melakukan tindakan reflektif; e) memanfaatkan teknologi informasi dan komunikasi.

4. Kompetensi sosial, yaitu terdiri dari, (a) bersikap inklusif, bertindak objektif, serta tidak diskriminatif dengan berbagai latar belakang yang beragam; (b) mampu berkomunikasi secara efektif, empatik, dan santun dengan sesama pendidik, tenaga kependidikan, orang tua, dan masyarakat; (c) bisa beradaptasi di tempat bertugas, di mana saja yang memiliki keragaman sosial budaya; (d) berkomunikasi dengan komunitas sesama profesi guru dan profesi lain.

Dari standar kompetensi tersebut, guru harus bisa menyesuaikan dengan jenjang pendidikan dan tugasnya. Sungguh berat tugas guru untuk memenuhi standar kompetensi, para guru ibarat "malaikat" yang bisa berbuat baik tanpa ada cela. Mencapai cita-cita ideal menjadi guru profesional yang dapat memenuhi empat kompetensi secara bersamaan dan terintergrasi bukan pekerjaan mudah. Pentingnya mengetahui pemahaman yang benar tentang wawasan dan landasan pendidik bagi guru harus jadi tanggung jawab moral dan akademik. Guru akan menyadari di mana mereka harus menempatkan diri sebagai orang yang harus menjaga keprofesionalannya dalam upaya mencapai tujuan negara, mencerdaskan kehidupan bangsa. ${ }^{13}$

Pendidikan memiliki peran dalam mengembangkan kepribadian anak bangsa secara utuh dan mampu mengelola budaya yang berkembang di tengah masyarakat. Pengembangan kepribadian seseorang itu dipengaruhi oleh faktor biologis, psikologis, sosial, dan budaya. Ketika budaya menjadi

\footnotetext{
${ }^{13}$ Jamil Suhartiningrum, Guru Profesional; Pedoman Kinerja, Kualifikasi, dan Kompetensi Guru (Yogyakarta: Ar-Ruzz Media, 2014), 65.
} 
faktor dalam pembentukan dan pengembangan kepribadian seseorang, maka guru sebagai pendidik harus memiliki wawasan tentang aneka ragam budaya. ${ }^{14}$ Seorang guru yang memiliki pengetahuan dan wawasan perkembangan masyarakat dan budaya, akan mengantarkan siswa untuk berpikir melewati problem budaya kekinian.

Guru yang bisa mengelola kelas dengan baik dan benar akan mampu memahami karakteristik atau kondisi psikologis peserta didik dalam proses pembelajaran. Tidak sedikit seorang yang ahli dalam ilmu tertentu tapi tidak mampu menyampaikan materi keilmuan yang dikuasainya kepada orang lain. Ilmuan hanya menguasai ilmunya untuk kepentingan kompetensi dirinya dalam menjalankan tugas amanah keilmuannya. Cara menyampaikan materi itu butuh kompetensi pedagogik. Tugas guru mengantarkan peserta didiknya agar bisa menerima informasi yang disampaikan, sekaligus siswa bisa mengambil inisiatif untuk memecahkan permasalahan yang ada di sekitarnya atau masalahnya sendiri. ${ }^{15}$ Penguasaan terhadap berbagai teori pendidikan, pembelajaran, dan kepemimpinan bagi guru merupakan sebuah keniscayaan. Sebagai usaha sadar, proses pendidikan, terutama saat di ruang kelas atau ruang belajar lainnya harus dilakukan oleh guru dengan sepenuh hati. Ada kesadaran untuk memahami bagaimana manajemen kelas bagi guru. Karena guru yang tidak mampu mengelola (sebagai bagian dari kepemimpinan pendidik) kelas dengan baik, ia akan mengalami kesulitan untuk bisa memberikan pemahaman yang benar kepada peserta didik. ${ }^{16}$ Agar guru bisa memenuhi target kompetensi dengan baik perlu ada strategi bagaimana cara meningkatkannya. Sehingga, guru sebagai pendidik profesional akan dapat terwujud. Dan tujuan pembelajaran sebagai bagian penting tujuan pendidikan (negara) akan tercapai.

\footnotetext{
${ }^{14}$ Muhammad Rifai, Sosiologi Pendidikan; Struktur dan Interaksi Sosial di dalam Institusi Pendidikan (Yogyakarta: Ar-Ruzz Media, 2011), 36-37.

${ }^{15}$ Jamil Suhartiningrum, Guru Profesional; Pedoman Kinerja, Kualifikasi, dan Kompetensi Guru (Yogyakarta: Ar-Ruzz Media, 2014), 104.

${ }^{16}$ Imam Gunawan, Manajemen Kelas; Toeri dan Aplikasinya (Depok: Rajagrafindo Persada, 2019), 10.
}

\section{Strategi Peningkatan Kompetensi}

Menurut pandangan umum, strategi bisa dikatakan sebagai upaya yang dilakukan oleh seseorang atau kelompok organisasi untuk mencapai tujuan yang telah ditetapkan. Ada penciptaan suasana dalam proses pelaksanaan strategi, sehingga dengan suasana yang kondusif memungkinkan siswa atau siapa saja yang ada dalam kelompok mencapai tujuan pembelajaran. Dikatakan strategi, menurut Stoner dan Sirait dalam Hamdani, apabila memiliki ciri-ciri dalam memiliki perencanaan waktu yang menggambarkan suasana masa depan, memiliki dampak, pemusatan kegiatan, pola pengambilan keputusan yang konsisten, dan alokasi sumber daya pada operasionalisasi sebagai spektrum kegiatan yang betul-betul terserap dengan baik. ${ }^{17}$ Sebelum dipakai di dunia pendidikan, strategi lebih identik dengan kegiatan militer, yakni kiat yang biasa digunakan para jenderal dalam merancang dan merencanakan peperangan untuk mencapai kemenangan. Seiring berkembangnya ilmu pengetahuan dan teknologi, strategi banyak dipakai dalam kegiatan organisasi dengan praktik yang beragam, namun ide pokoknya tetap memiliki kesamaan. ${ }^{18}$ Pun demikian dalam kegiatan olah raga, istialh strategi sangat familiar, karena dalam pertandingan olah raga tujuannya juga sama untuk memperoleh kemenangan.

Agar peningkatan kompetensi guru dapat dilaksanakan dengan baik, perlu penyusunan strategi yang dilakukan melalui; diagnosis, perencanaan, dan penyusunan dokumen. Pada tahap diagnosis, institusi atau lembaga pendidikan harus melakukan dua kegiatan, yakni analisis lingkungan internal dan lingkungan eksternal. Proses analisis dapat menggunakan SWOT (Strength, Weaknes, Opportunities, Threat). Semua sekolah memiliki visi dan misi, maka pengembangan selanjutnya dalam menyusun strategi harus mengetahui kebutuhan interal bagi guru dan tenaga kependidikan dengan memperhatikan isu-isu strategis yang berkembang. ${ }^{19}$ Jelas, setiap guru ingin mengembangkan dirinya, walau harus melakukan upaya secara mandiri. Apalagi jika sekolah atau

\footnotetext{
${ }^{17}$ Hamdani, Strategi Belajar Mengajar (Bandung: Pustaka Setia, 2011), 18.

${ }^{18}$ Sondang P. Siagan, Manajemen Strategi (Jakarta: Bumi Aksara. 2012), 16.

${ }^{19}$ E. Mulyasa, Manajemen \& Kepemimpinan Kepala Sekolah (Jakarta: Bumi Aksara, 2011), 165.
} 
madrasah memfasilitasi kebutuhan peningkatan kompetensi.

Sebagaimana disebutkan dalam UndangUndang Nomor 14 Tahun 2005 tentang Guru dan Dosen, bahwa guru merupakan pendidik profesional dengan tugas utama mendidik, mengajar, membimbing, mengarahkan, melatih, menilai, dan mengevaluasi. Untuk diakui sebagai tenaga profesional, seorang guru harus memperoleh sertifikat pendidik yang merupakan bukti pengakuan formal. Sertifikat tersebut tidak serta merta diperoleh seorang guru, sekalipun sudah memenuhi standar kualifikasi akademik. Ia harus mengikuti program pendidikan dan pelatihan yang diselenggarakan oleh pemerintah melalui lembaga penyelenggara pendidikan bagi tenaga kependidikan yang ditunjuk. Ada beberapa syarat dan ketentuan yang harus dipenuhi oleh setiap guru yang akan mengikuti program sertifikasi. Namun perlu diingat, bahwa setelah mendapat sertifikat sebagai tenaga profesional, maka harus pula diikuti dengan proses mempertahankan dan meningkatkan kompetensi, sehingga kedudukannya sebagai tenaga profesional akan tetap bisa dipertahankan.

Paling tidak ada tiga bidang yang harus dikuasai guru dalam menjalankan profesinya sehingga bisa disebut sebagai tenaga profesional, pertama yakni memiliki keahlian dalam ilmu dan teori pembelajaran. Kedua, memiliki ketrampilan penelitian, dan adapun yang ketiga ialah memiliki kompetensi dalam menjalankan amanat pengabdian kepada masyarakat. ${ }^{20}$ Tiga bidang ini idealnya terintegrasi dalam diri seorang guru, sehinga semakin berkembang kompetensinya. Problemnya, tidak semua guru mampu memiliki dan menguasai tiga bidang tersebut. Apalagi kalau sudah diberi beban tugas lain, seperti urusan administrasi yang banyak menyita tenaga, waktu, dan pikiran. Untuk mempertahankan ilmu dan teori pembelajaran yang pernah diikuti di bangku kuliah saja, sudah kesulitan. Lingkungan kerja dan pergaulan sangat menentukan seorang guru dalam menekuni bidang ilmu pembelajaran.

Hadirnya Undang-Undang No.14 Tahun 2005 tentang Guru dan Dosen sebenarnya bisa menjadi angin segar bagi guru. Negara hadir dengan

\footnotetext{
${ }^{20}$ Jamil Suhartiningrum, Guru Profesional; Pedoman Kinerja, Kualifikasi, dan Kompetensi Guru (Yogyakarta: Ar-Ruzz Media, 2014), 150.
}

memberikan intervensi langsung untuk meingkatkan kompetensi dan profesionalitas guru, sekurangkurangnya ialah strata satu (S1) atau D4, dan dapat sertifikat sebagai pengakuan atas kedudukannya sebagai tenaga profesional. Program sertifikasi yang sejatinya untuk meningkatkan kompetesi guru agar dalam melaksanakan tugasnya benar-benar profesional, sehingga tujuan pendidikan melalui proses pembelajaran dapat tercapai, nyatanya ada ketidaksesuaiannya. Sebagian hak keuangan guru karena sertifikat pendidik justru digunakan untuk meningkatkan kesejahteraan. Opini ini sebenarnya tidak salah, karena kesejahteraan guru memang menjadi tanggung jawab pemerintah. Jika guru secara ekonomi terpenuhi kesejahteraannya ada harapan besar proses pembelajaran akan fokus. Memang tidak bisa terbantahkan, bahwa dalam praktiknya guru yang sudah sertifikasi belum semua menunjukkan peningkatan kompetensi yang seharusnya dikuasai sehingga kinerja guru tercapai dengan baik.

Untuk memenuhi standar kompetensi guru sebagai tenaga profesional maka dilakukan Uji Kompetensi Guru dan Penilaian Kinerja Guru. Sebagai catatan, sebagaimana data Derap Guru dalam Agus Sutikno, pada tahun 2012-2014 telah dilaksanakan Uji Kompetensi Guru, dan hasilnya masih dikategorikan rendah dengan nilai rata-rata 47. Sejumlah 1.611.251 guru yang mengikuti Uji Kompetensi Awal - Uji Kompetensi Guru nilai yang paling banyak antara skor 40,1 - 50, dengan jumlah sebanyak 495.524. Perolehan skor 90,1 100 hanya 192 guru, dan yang nilainya di bawah 10 justru tergolong banyak, yakni 1.875 orang. Fakta ini menjadi keprihatinan dunia pendidikan, karena pemenuhan kompetensi menjadi faktor penting dalam penilaian kinerja guru. Padahal dalam uji kompetensi saat itu, target nilai minimal sebesar 7,00. ${ }^{21}$

Sekolah sebagai lembaga satuan pendidikan dapat memprogram kegiatan peningkatan kompetensi guru untuk pengembangan diri, setidaknya melalui 4 tahapan sebagai berikut: (1) menyusun analisis kebutuhan terhadap pelatihan dan pengembangan, (2) menentukan tujuan pelatihan; (3) melaksanakan pelatihan dan pengembangan secara baik dan benar;

\footnotetext{
${ }^{21}$ Agus Sutikno, Upaya Peningkatan Kompetensi Guru Melalui Pengembangan Diri dalam Prosiding "Profesionalisme Guru Abad XXI”, (Seminar Nasional IKA UNY, 2018), 47.
} 
(4) evaluasi program sebagai bahan pengembangan kompetensi selanjutnya. Empat tahapan ini sebenarnya tidak sulit, sekolah dengan kepemimpinan kepala sekolah yang baik bisa mendorong program pengembangan diri guru. Sekolah bisa kerja sama dengan lembaga perguruan tinggi atau lembaga mana pun. Bahkan pemerintah, baik pusat maupun daerah sering menyelenggarakan program peningkatan kompetensi guru. Secara mandiri, sekolah juga bisa mendorong guru untuk mengakses internet atau media lain, terutama bagi guru yang sudah sertifikat.

Banyak ragam bentuk kegiatan peningkatan kompetensi guru, baik secara kolektif maupun individu. Untuk kegiatan yang bersifat kolektif, antara lain meliputi :

1. Lokakarya, seperti Kelompok Kerja Guru (KKG), Musyawarah Guru Mata Pelajaran (MGMP), Musyawarah Kerja Kepala Sekolah (MKKS).

2. Pertemuan ilmiah dalam bentuk seminar atau diskusi kelompok.

3. Pendidikan dan pelatihan fungsional, dan kegiatan kolektif lain yang sesuai dengan tugas dan tanggung jawab guru dalam meningkatkan kompetensinya. ${ }^{22}$

Selain peningkatan kompetensi guru dalam proses pembelajaran, guru juga harus membuktikan pengembangan diri dengan banyak belajar mengenai teknik penulisan karya ilmiah yang baik dan benar. Bidang penelitian ini memang jarang diminati oleh guru. Masih banyak guru yang mengeluh karena beban tugas dan tanggung jawab, sehingga sibuk dan "menyibukkan diri", akibatnya bidang penelitian, yang salah satunya dibuktikan dengan menulis tidak banyak dilaksanakan. Sebagaimana diatur dalam Permenegpan Nomor 16 Tahun 2009 tentang Jabatan Fungsional dan Angka Kredit, banyak guru mengikuti pelatihan menulis karya ilmiah. Karena, salah satu syarat kenaikan pangkat adalah dengan membuktikan menulis karya ilmiah. Program pelatihan karya tulis ilmiah banyak diselenggarakan oleh organisasi profesi, kelompok kerja guru, perguruan tinggi, dan sebagainya. Agar para guru mau menulis, pemerintah

\footnotetext{
${ }^{22}$ Mulyasa, Uji Kompetensi dan Penilaian Kinerja Guru (Bandung: Rosda, 2013), 173.
}

pun akhirnya memberikan bantuan keuangan yang diberikan kepada organisasi Kelompok Kerja Guru (KKG) dan Musyawarah Guru Mata Pelajaran (MGMP).

Untuk meningkatkan kompetensi guru, pertama adalah penyaringan atau seleksi calon guru dengan memperhatikan aspek moral dan kualitas. Kedua, mendorong para guru agar memperoleh kesempatan pendidikan yang lebih tinggi, melalui program beasiswa atau inisiatif sendiri. Ketiga, memotivasi guru agar mau mengikuti kegiatan di luar tanggung jawabnya di sekolah, seperti pelatihan, workshop, kursus, seminar, baik yang diselenggarakan sekolah atau pun madrasah sendiri atau lembaga lain. Keempat, tindak lanjut kegiatan dengan mengadakan pertemuan rutin untuk memelihara pertemenan sejawat, menumbuhkan semangat kekeluargaan, dan solidaritas di antara teman.

\section{Mutu Lulusan}

Secara ideal, sekolah yang memiliki guru dengan kompetensi baik akan menghasilkan lulusan yang baik. Proses pembelajaran dengan tenaga pendidik profesional akan mampu mengembangkan potensi peserta didik, yakni mereka yang menguasai ilmu yang telah diberikan guru melalui proses pembelajaran, sebagaimana tujuan pembelajaran yang ditetapkan oleh guru. Peserta didik memperoleh berbagai pengetahuan, terbentuknya sikap, dan ketrampilan dalam mempraktikkan ilmu yang dikuasai. Saat merencanakan, melaksanakan, menilai, dan mengevaluasi pembelajaran, guru melakukannya berdasarkan kompetensi yang dikuasai, misalnya kompetensi pedagogik dan profesional. Dengan demikian, sekolah akan dikatakan bermutu atau berkualitas apabila melahirkan lulusan yang memiliki mental kompetitif, mampu melanjutkan ke jenjang pendidikan tinggi, dan memiliki keterampilan tertentu sebagai bekal memasuki duni industri.

Kita tahu, bahwa sekolah merupakan institusi strategis dalam mengembangkan sumber daya manusia. Sehinga benar dikatakan, bangsa yang maju dan bermartabat, indikatornya dapat kita lihat ketika pengembangan sumber daya manusianya melalui institusi pendidikan berlangsung dengan baik. Untuk membentuk watak bangsa dan peradaban yang bermartabat, pemerintah dengan kewenangannya 
sudah bisa memberikan perhatian lebih dalam urusan pemerintahan bidang pendidikan. Amanat konstitusi dan peraturan perundang-undangan yang mengatur penyelenggaraan dan pengelolaan sistem pendidikan sudah mendukung ke arah tercapainya mutu sumber daya manusia berkualitas, dengan kebijakan alokasi anggaran pendidikan yang cukup "memadai", minimal 20\% dari Anggaran Pendapatan dan Belanja Negara/Daerah.

Salah satu komponen penting dalam dunia pendidikan adalah hadirnya guru yang memiliki kompetensi dalam proses pembelajaran. Guru yang profesinonal akan mudah dalam mengemban amanah, tugas dan tanggung jawabnya dalam rangka mengantarkan peserta didik untuk mengembangkan potensi. Sebagaimana dijelaskan di atas, bahwa tantangan besar dunia Pendidikan adalah ketatnya persaingan di semua lini kehidupan akibat laju teknologi yang begitu cepat dan pesat. Menghasilkan lulusan yang bermutu tentu harus didukung oleh manajemen mutu sekolah. ${ }^{23}$ Konsep manajemen mutu merupakan paradigma baru dalam penyelenggaraan pendidikan. Pemberian otonomi sekolah/madrasah menjadi peluang bagi percepatan peningkatan mutu pendidikan, meningkatkan kinerja guru, dan memberikan partisipasi masyarakat. Dengan adanya partisipasi masyarakat, penyelenggara pendidikan akan terus melakukan inovasi. Pada dasarnya, konsep manajemen mutu ini lahir dari konsep manajemen berbasis sekolah atau madrasah. ${ }^{24}$

Dengan dukungan tenaga pendidik profesional, memiliki kompetensi secara holistik dan terintegrasi, seharusnya berbanding lurus dengan mutu lulusan sekolah atau madrasah. Implementasi standar pendidik dan tenaga kependidikan, standar kompetensi lulusan, dan standar proses, satu sama lain tali temali dalam proses pembelajaran, selain dukungan Standar Nasional Pendidikan yang lain. Guru bukan saja dituntut memenuhi standar kualifikasi dan kompetensi, tapi guru juga harus memahami standar lainnya yang sudah ada dalam beberapa ketentuan peraturan perundangundangan. Persepsi masyarakat akan terbangun

\footnotetext{
${ }^{23}$ Yen Chris Tien, "Manajemen Peningkatan Mutu Lulusan", Jurnal Manajer Pendidikan, Vol. 9, No 1, (Juli, 2015), 580.

${ }^{24}$ Prim Masrokan Mutohar, Manajemen Mutu Sekolah: Strategi Peningkatana Mutu dan Daya Saing Lembaga Pendidikan (Jogjakarta: Ar-Ruzz Media, 2013), 123.
}

dengan baik manakala lulusan dari suatu lembaga pendidikan benar-benar menunjukan kualitas yang baik. Beberapa indikator sekolah atau madrasah dianggap bermutu atau bahkan dinyatakan sebagai bermutu oleh masyarakat ketika banyak lulusan memiliki nilai atau prestasi akademik. Apalagi pada saat ini fenomena yang mengitari generasi milenial begitu kompleks, baik itu globalisasi, wesernisasi dan pengikisan moral. Oleh karena itu, pesantren atau madrasah dalam hal ini mempunyai kiprah yang begitu vital dalam mempersiapkan generasi emas di masa depan. Generasi milenial yang terkungkung dengan kedahsyatan pengaruh teknologi dan informasi dapat diatasi dan diminimalisir melalui pendidikan ala pesantren yang mengandung nilai-nilai keseimbangan antara duniawi dan ukhrawi, aspek sosial dan spiritual, aspek jasmani dan rohani, dan lain sebagainya. ${ }^{25}$ Dengan demikian, secara linier para lulusannya akan bisa dilihat sejauhmana mereka melanjutkan pendidikan, menjadi tenaga profesi di beberapa dunia usaha, dan lain sebagainya. Kompetensi yang memadai sehingga mendukung terhadap pelaksanaan tugas dan tanggung jawab, dan memiliki etos kerja yang kuat sejalan dengan apa yang difirmankan Allah dalam QS. al-An'am ayat 135:

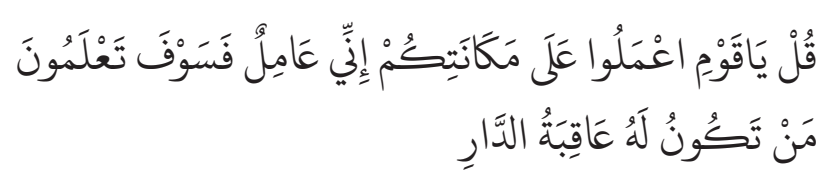

Artinya: "Katakanlah: Hai kaumku, berbuatlah sepenuh kemampuanmu, sesungguhnya akupun berbuat (pula). Kelak kamu akan mengetahui, siapakah (di antara kita) yang akan memperoleh hasil yang baik di dunia ini."

Surat ini menginspirasi bagi para guru agar ketika melaksanakan kewajibannya menunjukkan kesungguhan, memperhatikan kompetensi, dan tujuan pembelajaran yang sudah disusun dalam perencanaan pembelajaran. Melakukan pekerjaan dengan sungguhsungguh, memperhatikan keterampilan, etos kerja, dan tanggung jawab sebagai mahluk Tuhan, maka akan mendapatkan hasil yang baik.

\footnotetext{
${ }^{25}$ Moh. Nawafil dan Hafifuddin Nur, "Pendidikan Indegenous Ala Pesantren untuk Memperkokoh Karakter Generasi Milenial", Edupedia: Jurnal Studi Pendidikan dan Pedagogi Islam, Vol. 5, No. 1, (Juli, 2020), 17.
} 


\section{SIMPULAN}

Menjadi guru yang memiliki kompetensi adalah keniscayaan dan kewajiban yang tidak terelakkan. Sudah banyak membuktikan, bahwa ketika guru melaksanakan proses pembelajaran dengan penuh semangat, menyenangkan, kreatif, inovatif, dan komunikatif akan memberikan dampak bagi pengembangan potensi peserta didik. Keempat kompetensi guru, yakni kompetensi pedagogik, profesional, kepribadian, dan sosial bukanlah berdiri sendiri, tetapi harus terintegrasi secara holistik. Untuk mencapai kompetensi yang sempurna sesuai tujuan penyelenggaraan pendidikan yang ditetapkan oleh pemerintah maupun satuan pendidikan, guru harus berupaya secara intrinsik dalam proses peningkatan kompetensi. Sebagai dukungan terhadap peningkatan kompetensi guru, pemerintah sudah memberikan bantuan berupa fasilitasi pelatihan dan program lain. Guru dan atau sekolah harus bisa merespon dengan baik dengan tetap menyusun strategi peningkatan kompetensi. Kompetensi guru yang semakin profesional, tentu dapat memcahkan persoalan dunia pendidikan yang carut-marut, salah satunya masalah akhlak. Sehingga sehingga mutu lulusan yang dihasilkan adalah lulusan yang berkarakter, religius, memiliki seperangkat pengetahuan kognitif, afektif dan psikomotorik.

\section{DAFTAR RUJUKAN}

Efendi, Nur Manajemen Perubahan di Pondok Pesantren. Yogyakarta: Teras, 2014.

Gunawan, Imam. Manajemen Kelas; Toeri dan Aplikasinya. Depok: Rajagrafindo Persada, 2019.

Hamdani. Strategi Belajar Mengajar. Bandung: Pustaka Setia, 2011.

Kunandar. Guru Profesional, Implementasi Kurikulum Tingkat Satuan Pendidikan (KTSP) dan Sukses dalam Sertifikasi Guru. Jakarta: Rajawali Press, 2011.

Mahmud. Sosiologi Pendidikan. Bandung: Pustaka Setia, 2012.

Maksum, Ali dan Yunan Ruhendi Luluk. Paradigma Pendidikan Universal di Era Modern dan PostModern. Yogyakarta: IRCiSoD, 2004.
Nawafil, Moh. dan Hafifuddin Nur. "Pendidikan Indegenous Ala Pesantren untuk Memperkokoh Karakter Generasi Milenial”, Edupedia: Jurnal Studi Pendidikan dan Pedagogi Islam, Vol. 5, No. 1, (Juli, 2020).

Mulyasa, E. Manajemen \& Kepemimpinan Kepala Sekolah. Jakarta: Bumi Aksara, 2011.

Mulyasa, E. Uji Kompetensi dan Penilaian Kinerja Guru. Bandung: Rosda, 2013.

Musfah, Jejen. Peningkatan Kompetensi Guru Melalui Pelatihan dan Sumber Belajar Teori dan Praktik. Jakarta: Kencana Prenada Media Group, 2012.

Mutohar, Prim Masrokan. Manajemen Mutu Sekolah: Strategi Peningkatana Mutu dan Daya Saing Lembaga Pendidikan. Jogjakarta: Ar-Ruzz Media, 2013.

Peraturan Menteri Pendidikan Nasional Nomor 16 Tahun 2007 tentang Standar Kualifikasi Akademik dan Kompetensi Guru

Peraturan Pemerintah Nomor 19 Tahun 2005 tentang Standar Nasional Pendidikan

Permenegpan Nomor 16 Tahun 2009 tentang Jabatan Fungsional dan Angka Kredit.

Rifai, Muhammad, Sosiologi Pendidikan; Struktur dan Interaksi Sosial di dalam Institusi Pendidikan. Yogyakarta: Ar-Ruzz Media, 2011.

Rusman. Model-Model Pembelajaran; Mengembangkan Profesionalisme Guru. Jakarta: Raja Grafindo Persada, 2011.

Siagan, Sondang P. Manajemen Strategi. Jakarta: Bumi Aksara. 2012.

Suhartiningrum, Jamil, Guru Profesional; Pedoman Kinerja, Kualifikasi, dan Kompetensi Guru. Yogyakarta: Ar-Ruzz Media, 2014.

Sutikno, Agus. Upaya Peningkatan Kompetensi Guru Melalui Pengembangan Diri dalam Prosiding "Profesionalisme Guru Abad XXI". Seminar Nasional IKA UNY, 2018.

Tien, Yen Chris. "Manajemen Peningkatan Mutu Lulusan”, Jurnal Manajer Pendidikan, Vol. 9, No 1, (Juli, 2015). 